\title{
Barriers to Knowing Inside: Education in Prisons and Education on Prisons Justin Piché
}

...the more we learn, the more aware we become of injustice, inequality, death, and suffering which affect huge numbers of human beings who inhabit our planet. And the more we learn, the more we develop a sense of responsibility to do something to make the world a better place (Terry, 2004, p. 29).

\section{Education in Prisons}

Tn an environment frequently described as dangerous, overcrowded 1 and destructive, many prisoners have cited voluntary participation in education programs such as vocational training, basic literacy, high school equivalency, post-secondary courses and peer-to-peer teaching as the only positive experience one may encounter while incarcerated. The benefits are particularly pronounced when examining the impact of higher education. It is shown that those who obtain post-secondary accreditation in prison are much less likely to recidivate (Huckelburry, 2004). They also find themselves in a better position to secure well paid long-term employment (Taylor, 1989; 2004a) and to continue their studies upon release (Deutsch, 2004). Taken as a whole, "[u]niversity study has been demonstrated by research to be the single best means to post-prison success" (Richards, 2004, p. 70).

Advantages of these programs extend to prison officials who "report that the prisoners who are involved in educational programs are more easily managed, present fewer problems, and are less of a threat to their counterparts and staff' (Nagelsen, 2004, p. 138). Beyond utilitarian imperatives associated with success in the 'correctional' realm, prison writers have reported a number of other beneficial aspects of taking part in educational activities. Through the acquisition and development of the tools needed to make sense of the world and one's place in it (Murphy, 1998, p. 49), students gain the power "to bring about social, political, and economic changes" (Saleh-El, 1992). Historically, this has been the case. For instance, peer-based political education was vital to the success of Irish republican prisoner struggles:

For all involved in the political education process within the jail it was not simply about the learning of new concepts and theories. It was 
also about the acquiring of new values and the construction of a new society. At the same time that society was not utopian or idealistic but firmly rooted in the realities of the real conditions of the jail and the level of development of the Movement on the outside... It was within this new construct of the 'politically aware', the 'critical', the 'tactical revolutionary' that we formulated all future assaults upon the prison authorities" (McKeown, 2001, p. 148).

By reasserting a sense of control over their lives in this manner, prisoners build their self-esteem, confidence and feelings of well-being (Taylor, 2004a, p.76).

While noting the positive aspects of prison education programs, JPP contributors have critiqued these initiatives for their role in social control. It is argued that in a setting where one "is told what to do, when to do it, how to do it, and where to do it" (Saleh-El, 1992), opportunities to learn are often used as tools to manage those captive (MacLean, 1992). As these initiatives operate at the whim of prison administrators and staff (Bell, 1992; Murphy, 1998, p. 43), the 'logics' of security and punishment tend to triumph, often taking precedence over the imperatives of learning (Jones, 1992). The following passages describe the precariousness of education inside carceral institutions:

I witnessed educational events being cancelled on a moment's notice for "security reasons". I had seen guards flex their muscle and return men to their cells without provocation, thereby undermining the educational process, and I had watched as men were treated with disrespect and left with little or no human avenue for defense (Nagelsen, 2004, p. 138).

Lockdowns (where prisoners are confined to their living area), institutional recalls (where prisoners must report to those living areas, at least temporarily), and foggy weather all shut classes down. These situations occur regularly. Therefore, learning continuity, which is such an essential factor in the success of any educational endeavor, is interrupted (Deutsch, 2004, p. 102).

Instances such as those described above are not surprising given the potential threat that individuals transformed by learning pose to institutions that think in black and white. Finding ways to displace education in these manners is "the logical strategy for prison administrators ... to keep prisoners ignorant to prevent the acquisition of any high-minded ideas, 
lest we begin to question our subjugation and treatment" (Huckelburry, 2004, p. 33).

In prison, as in other 'social' institutions, the focus of education is often the promotion of "social utility and conformity" (Hassine, 1997, p. 37). The preservation of the status quo is championed in places of confinement through 'offerings' that are seldom mindful of socio-economic disparities and ethnicity (Rivera, 1992). It is also important to note the gendered orientation of prison education programs, particularly in the case of educational opportunities extended to women prisoners which often exclude vocational training (Bonfanti, 1992; Bell, 1992). Such instances reinforce patriarchal notions of labour division in society. Seen in this light, the success of participants is in more cases than not achieved "in spite of, rather than because of, the various "curricula"' (Lynes, 1992).

In lieu of these systemic hurdles, many including Dana and McMonagle (2004) have argued that the formation of systems of self-education is vital to learning while deprived of one's freedom. However, even attempts to amass knowledge independently have been under attack. This is especially visible in the United States, where in some jurisdictions prisoners do not have access to bookseller inventories and cannot purchase hardcover books (Ainsworth, 2004, p. 15). Even worse, some "are required to submit a synopsis of the book to obtain purchase approval, and unless we can obtain a catalog or can get an information sheet from the bookseller, we are up the crick or in the proverbial Catch-22" (ibid). For those interested in building their knowledge of the legal system to which they owe their enslavement, they find a judiciary complicit in their de-education as illustrated by "the US Supreme Court's decision a few years ago stating that prison systems need not maintain a law library (Lewis v. Casey, 518 US 343 [1996])" (ibid, p. 14).

Another major hurdle to knowing inside is the lack of prisoner participation in educational programming (Rucier, 2004). An informal survey which examined the reasons prisoners chose not to participate in adult basic education courses revealed the following:

...the majority of men did want an education, but they felt out of place in ABE classes. A main reason they gave was fear. They feared being laughed at by other prisoners, many of whom are neighborhood friends. We understood their reasons and feelings. In prison, image can be survival (Graves, 2004, pp. 92-93).

In the case of post-secondary education, "[n]ot all inmates will qualify for, or be interested in, such opportunities" (Taylor, 1989, p. 62). That being 
said, it is important that avenues for learning "be expanded so that no prisoners are denied a chance to better themselves" (Harris, 2004, p. 58).

In addition to the barriers outlined above, perhaps the greatest ongoing threat to already scarce education initiatives inside prisons are "budget cuts and changes in the tide of bureaucratic or public opinion" (Graves, 2004, p. 94). These tensions are heightened in times of economic uncertainty where misinformed individuals believe funds earmarked for post-secondary prison education are taking away from those allocated for the schooling of 'law-abiding' citizens. They are of the perspective "why-should-they-get-an-education-for-free-when-I-will-have-to-worktwo-jobs-and-go-into-debt-to-put-my-son/daughter-through-college" (Nagelsen, 2004, p. 134). Politicians and prison officials have fostered and mobilized these sentiments to dismantle higher education in carceral institutions in Canada, the United States and elsewhere in the world. For instance, in 1993 the Correctional Service of Canada shut down university accreditation programs citing budgetary shortfalls and the need to shift these resources to target the 'criminogenic' propensities of prisoners (Murphy, 1998, p. 40). This move "hardly bears scrutiny since the monies allocated for university programming were minuscule to say the least in terms of CSC budgeting" (ibid). South of the border, legislation was passed by American lawmakers in 1994 that prohibited prisoners from applying for Pell Grants made available to individuals in financial need who wished to pursue a post-secondary education (Taylor, 1998). The passage of this unjust law had a significant impact:

Almost immediately, half the prison college classes across the country were closed, and opportunities in most surviving programs were reduced as well. Today, the only access the majority of convicts have to post-secondary education is through traditional correspondence classes, less well-known university end-of-course exams, and even less publicized equivalency tests (Taylor, 2004, p. 74).

Without access to educational financial aid, such as the old Pell Grants (less than one percent of all Pell Grants actually went to prisoners), the prohibitive costs of accredited college level correspondence courses and the difficulties in obtaining them (requiring the co-operation of the prison's Education and Mailroom departments) make it nearly impossible to pursue this avenue of credit earning and possible degree attainment in higher education from the depths of Death Row (Ainsworth, 2004, p. 13). 
But why remove the opportunity to learn from prisoners who without an education are likely to return to prisons, contributing to the continued growth of carceral populations? Nearly two decades ago, Taylor (1989) noted that the prison boom in the United States and expanding 'correctional' budgets were contributing to the erosion of funds for education not only for prisoners, but also the general public. We need to be reminded that for every new prison built funding for a new post-secondary institution is lost, that a new prison guard hired empties coffers that could provide ten deserving students much needed tuition scholarships in a given year, and that one security camera mounted inside deprives a pupil the assistance to buy compulsory textbooks needed for class. As the "money for this massive and already delinquent building program has to come from somewhere at the expense of someone else" (Taylor, 1989, p. 58), the rhetoric which divides and conquers those inside and outside needs to be exposed for what it is.

\section{Educhtion on Prisons}

While the need to make visible what takes place inside prison walls is greater today than any previous point in history, opportunities to provide such an education are few and far between. For the most part, we do not know about how incarceration is experienced by captives and their captors (Simon, 2000; Wacquant, 2002). There are many factors which have contributed to this crisis in knowing inside.

In a context where scholarship was seen as an integral component in helping to transform austere carceral institutions into bastions of rehabilitation, scholars such as Clemmer (1940) and Sykes (1958) were allowed to enter prisons. Influenced by the ethnographic work emanating from the Chicago School, these academics examined the social dynamics and processes of imprisonment. During this period described as the "golden age of prison sociology" (Simon, 2000, p. 285), the brutalities of the prison world were exposed.

The situation changed as 'crime' and punishment became a hot political issue in the late 1960s. In this climate, the institutional predisposition to avoid scrutiny through secrecy coupled with the displacement of rehabilitation as the chief concern of 'corrections' (Wacquant, 2002, p. 384), led prison officials to effectively bar social scientists from carceral settings. Activists were also "barred from prison", as shown in the three books written by Claire Culhane $(1979 ; 1985 ; 1991)$ which attest to the difficulties faced by those who wished to gain access to Canadian prisons in the wake of disturbances and riots in the 1970s. Taking their 
place were technocrats schooled in "risk prediction, accounting, systems engineering, and the like" (Simon, 2002, p. 303).

It should be noted that ethnographic work has not completely disappeared from the penological landscape. Feminist scholars interested in reconstructing history and contemporary developments through the perspectives of women (Carlen, 1983; Adelburg and Currie, 1987; Comack, 1996; Bosworth, 1999; Martel, 2001), and academics influenced by functionalist and symbolic interactionist traditions (Liebling et al., 1999; Crewe, 2005; Inderbitzin, 2007), have managed to navigate barriers to conduct meaningful studies on imprisonment. By merging "their past with their present" (Richards and Ross, 2004, p. 115), former prisoners turned professors who work under the Convict Criminology banner have also been able to develop grounded accounts of contemporary prison life. Notably absent in this literature are neo-Marxist and neo-Foucauldian analyses of carceral experiences. Instead, those belonging to these dominant traditions in critical criminology tend to direct their attention towards theorizing the quantity of imprisonment while ignoring its qualitative aspects. As a result, the pool of credible material from which one can draw in an effort to convince others of the destructive character and horrifying impacts of incarceration is quite small.

\section{Prison Writing as Education}

As discussed above, there are limited opportunities and significant barriers to knowing inside prison walls, both to prisoners who work towards enhancing their education and to scholars who wish to examine the inner workings of carceral institutions. Given the current levels of punitiveness being expressed in our penal systems and the continued politicization of 'corrections', it is unlikely that authorities will provide interested parties with openings to reverse these connected trajectories. With these developments in mind, it is imperative that proponents of education in prisons encourage prison writing as a knowledge advancement practice.

According to many JPP contributors, motivations for writing inside prison walls are quite similar to prison education program participation, particularly for reasons that are intimately linked to their personal survival and resistance to the shackles placed on them by society (Abu-Jamal, 1989, p. 29). As discussed by Clemmer (1940), Sykes (1958), Goffman (1961), Cohen and Taylor (1972) and most prison writers, the day-to-day processes and brutalities one encounters in prisons strip one's sense of self, control and connectedness to the world. By writing, prisoners reacquaint themselves with the one of the most basic freedoms - expression (Horii, 
1988-1989). Similarly, writing also provides opportunities for prisoners to get in touch with their senses which have been numbed in prison, allowing their "creative juices to flow" (McMaster, 2002, p. 64), contributing to psychological and intellectual well-being (Rafferty, 2004, p. 52). In this sense, expression becomes both therapeutic and rehabilitative as prisoners are able to engage in constructive work that allows them to sort out their often troubled pasts, to regain self-esteem, to build portfolios, and to make a contribution to the world in an environment that is otherwise negative and unproductive (McMaster, 2002, pp. 64-66).

Above all, writing provides a forum through which a prisoner cut off from the world can "rejoin society as a productive human being" (Hassine, 2002, p. 63) to achieve broader aims. Through analytical essays, commentaries, scholarly articles, autobiographies and the like, these writers give "insight into the perspectives and understanding of prisoners and the everyday experience of prison life" (Gaucher, 1989, p. 4). Such contributions raise political consciousness around the struggles faced by prisoners (Ghuanna, 2002, p. 74). This is also accomplished through advocacy that mobilizes support in the form of letter writing campaigns and organized protests on the 'inside' and 'outside' (Wright, 2002, p. 81). Attempts to raise political consciousness also involve cultural struggles articulated through song, poems, plays, comics, drawings, paintings, and carvings (Ghuanna, 2002, p. 71). Through such activities, prisoners attempt to re-enter public debates on crime and punishment to "help halt the disastrous trend toward building more fortresses of fear which will become in the 21 st century this generation's monuments to failure" (Mayhew, 1988, p. 11). By "making a record of the wrongs", prisoners have a "better chance of success than quiet solitude in the meek hope of not being hurt for not being heard" (Taylor, 2004b, p. 130).

In the realm of academia, it has been argued that if one is interested in understanding the experience of prisoners, the researcher must seek their accounts and take record of their narratives through ethnographic research (Wacquant, 2002). By engaging in such activities, it is believed that one is able to best capture the complexity of the relationships that exist in carceral institutions (ibid). To restate the obvious yet clearly ignored, if one wants to make sense of imprisonment one must conduct research by interacting with prisoners. Such a viewpoint situates the academic as the only actor capable of developing authoritative knowledge on the social processes and dynamics of prison life.

This sentiment is not shared by imprisoned intellectuals, also known as prisoner ethnographers, who argue that it is not enough to extract information from them in order to capture the reality of imprisonment. As 
they have first-hand knowledge of the hard realities of incarceration, it is a shared belief amongst this community of writers that "anyone who has not done time cannot possibly know what it is like and therefore cannot write competently about it" (Hucklebury, 2002, p. 52). This position is also supported by McMaster (2002), who argues that one is best situated to write about particular sets of experiences when such issues have played a part in the formation of their personal biographies. Such an epistemological position challenges the claim made by criminologists who argue that knowledge on prisons and prisoners can be adequately constructed at a distance without prisoners as informants (Piché, 2006, p. 78-79). It also allows for the deconstruction of accounts and theorization on the 'criminal justice' process produced by 'outsiders', including the categories used to make sense of the experiences of prisoners (Gaucher, 2002, p. 21).

As with other knowledge building activities within the walls of carceral institutions, those who write in prisons face many hurdles. For instance, being in prison means that one is stripped of many of the resources needed to express one's ideas intelligibly (Richards and Ross, 2004, p. 120). McMaster (2002) notes that his research is hampered by his lack of access to the Internet and to core texts, many of which are deemed to be inadmissible due to the alleged risk they pose to institutional security. Prisoners also experience censorship through the monitoring of correspondence which is subjected to rigorous screening processes and regulations (Wright, 2002, p. 88). If one manages to collect books and articles over time, the "minute our writings aggravate a high ranking corrections official or some other government bureaucrat, the files and books are deemed to be a fire hazard and confiscated" (McMaster, 2002, p. 68). Equipment used to write such as pens, typewriters and computers can also be confiscated (ibid, p. 66). Prison writers can also "suffer the retribution of prison authorities, including denial of parole, loss of goodtime credit, physical threats from staff or inmates, frequent cell searches, confiscation of manuscripts, trips to 'the hole', and disciplinary transfers to other prisons" (Richards and Ross, 2004, p. 120). If not chastised by their captors, prison ethnographers are often threatened by fellow prisoners who do not want the outside world to become aware of what takes place on the 'inside' (McMaster, 2002, pp. 68-69). Furthermore, many writers inside are on occasion discouraged to write by their families, who claim to experience humiliation when their work is published.

Should prison writers evade these forms of censorship they also face a final major hurdle, as they have to find a publisher in a less than supportive literary community (Hassine, 2002, p. 63), which often voices disbelief 
of their accounts and also wishes to evade unwanted public scrutiny (McMaster, 2002, p. 69). If published, prisoners also face hostility from the public who believe the "club-fed" rhetoric that claims prisoners are not being punished enough by pointing to the televisions and radios in their cells. Thus, not only is the writing process made problematic for prisoners, finding an audience for their work is extremely difficult (Hassine, 2002, p. 58).

When considering the contributions of prison writing to education inside and outside prisons made in spite of all constraints, forums such as the JPP are vital to helping prisoners transcend the shackles that aim to stifle their minds. As the armies of social control who hold millions upon millions captive continue to grow at more than alarming rates, projects of knowing inside have never been more important.

\section{ThIs Issue}

As this is the first volume published by the new JPP collective, we thought it would be an appropriate time to explore some of the barriers to developing knowledge while imprisoned and on imprisonment. In the process, an understanding of the need for prison writing in this era of mass incarceration was once again renewed.

The barriers to prison education are many. As noted by Jon Marc Taylor in "Pell Grants for Prisoners: Why Should We Care?", a major hurdle faced by prisoners who wish to obtain a post-secondary education behind bars is erected in the realm of politics. In revisiting the elimination of Pell Grants in the United States and its impacts, Taylor makes the case that "it is time" to reverse the trajectory in order to improve the lives of prisoners and reduce recidivism rates, providing "the possibility of a better future for all Americans". Scott Steffler's discussion in "Oregon's Anti-education "Corrections" Policy: A Surprise?" takes us beyond electoral politics, to consider the institutional barriers faced by those who pursue higher education in prison. Drawing on his experience, Steffler's piece illustrates how the discretionary powers afforded to 'correctional' officers can be used to obstruct and all-together thwart one's educational progress.

In crisis there is opportunity. As noted by Eugene Dey in "Higher Education in Prison: The Palo Verde Model", there is a crisis in postsecondary education in the State of California, largely caused by the diversion of funds once earmarked for such programming to build prisons in recent decades. As places of higher learning struggle to survive, a few institutions have turned to the provision of post-secondary education to prisoners through correspondence to maintain the necessary numbers 
to stay afloat. In "Convict Criminology Courses at the University and in Prison", Stephen Richards, Donald Faggiani, Jed Roffers, Richard Hendrickson and Jerrick Krueger provide an overview of the University of Wisconsin Oshkosh's Inviting Convicts to College initiative. This project provides prisoners with an introduction to criminology through the Convict Criminology perspective along with key information needed to bridge from one total institution (the prison) to another (the university). While the interviews with prisoners conducted by Dey and the excerpts from the surveys administered by Richards et al. highlight the positive aspects of these arrangements, the existence of such schemes highlights the absurd fact that the small government rhetoric of neo-liberalism has laid the groundwork for the dismantling of welfare apparatuses to fund the expansion of domestic and foreign warfare (see Gilmore, 2007), leaving us to make the best of a bad situation.

The issue then turns to Canada, which in the global 'correctional' community is often heralded as a model system whose policies, practices and programs are to be emulated. Pieces by Rod Carter and Peter Collins challenge this view. In "My Experience With Education in Canada and Federal Prisons", Carter, a former prisoner and Prison Chaplain for the Correctional Service of Canada (CSC), takes us through his educational journey in an effort to highlight its capacity to open doors and transform lives. However, he makes the point that CSC's "forced education" approach, which makes participation in basic education a compulsory component of their case management plan, undermines this potential. Carter is also critical of CSC's policy to "not pay for university courses as they once did". Collins extends this critique by highlighting the ways in which CSC's brand of 'correctional' education teaches its pupils more about how the system obstructs personal growth than it provides tools to succeed in society.

As previously noted, there are few opportunities for academics to enter prisons to find out what is going on inside. In "Prison Visits: On the Outside Looking In", Victoria Simpson Beck, Stephen Richards and Preston Elrod explore the benefits of prison visitation for academics who wish to learn about the realities of the prison system from the incarcerated. More importantly, they highlight how prison visitation benefits prisoners who are largely deprived of contact with the outside world and how this in turn can contribute to their safe reintegration into society upon release.

In a context where educational opportunities for prisoners are few and far between, Susan Nagelsen forcefully argues that prison writing plays a vital role in helping prisoners develop their intellect and to "counter the stultifying existence they encounter daily". We are also reminded 
that while prison writing offers one of the few windows into carceral institutions the barriers are many, as illustrated by the confiscation of the articles contained in this volume sent to Taylor that were to form the basis of his Response to the issue. In our march to make visible that which the authorities wish to keep invisible, Taylor in "What We Have Continued to Exemplify" encourages us to continue to "fight the good fight".

In this spirit, the Prisoners' Struggles and Book Reviews sections include resources for prisoners along with contributions from individuals and groups working towards expanding knowledge inside including Seth Ferranti, Eugene Dey and books2prisoners Ottawa. A call for contributions from the UN Special Rapporteur on Education who is currently examining whether the right to education outlined in article 26 of the 1948 Universal Declaration of Human Rights is being respected in places of detention is also included.

Through writing, contributors to the JPP continue to document and critique "the nature, functions, and significance of educational programs" inside prisons (Davidson and Taylor, 2004, p. 1). As "education must never be treated as or considered a privilege" (Harris, 2004, p. 59), it is my hope that these pieces evoke a sense of responsibility amongst our readers to support, promote and participate in opening the doors to learning to all who thirst for knowledge.

\section{JPP MOVIng Forward}

In November 2007, the JPP began a renewal process involving the reconstitution of our Editorial Board in order to inject new life into the initiative. Since that time, we have added a number of current and former prisoners, and academics. We continue to base our operations at the University of Ottawa Press, remaining committed to disseminating prison writing that explores the contours of imprisonment in a context where incarceration is becoming normalized and is expanding beyond the confines of the penal system.

As we release the first issue as a collective, we would like to take this opportunity to thank Bob Gaucher for exposing us to prison writing, giving us this opportunity to work on this unique project, and for his encouragement and advice during the renewal process. We would also like to thank those who have contributed pieces to the $J P P$ over the years and look forward to working with all prisoners who wish to engage in writing as resistance. To our readers, we would like to thank you for your continued support of this forum for education inside and outside prison walls. 


\section{REFERENCES}

Abu-Jamal, Mumia (1989) "Revolutionary Literature = Contraband", Journal of Prisoners on Prisons, 2(1): 25-29.

Adelberg, Ellen and Claudia Currie (1987) Too Few to Count: Canadian Women in Conflict with the Law, Vancouver: Press Gang Publishers.

Ainsworth, Steven K. (2004) "Deliberate Indifference", Journal of Prisoners on Prisons, 13: 12-15.

Bell, Gay (1992) "On Prison Education and Women in Prison: An Interview with Therasa Ann Glaremin”, Journal of Prisoners on Prisons, 4(1): 35-40.

Bonfanti, Cheryl (1992) "A Chance to Learn”, Journal of Prisoners on Prisons, 4(1): 41-44.

Bosworth, Mary (1999) Engendering Resistance: Agency and Power in Women's Prisons, Aldershoot (UK): Ashgate.

Carlen, Pat (1983) Women's Imprisonment: A Study in Social Control, London: Routledge \& Kegan Paul.

Clemmer, Donald (1940) The Prison Community, Boston: The Christopher Publishing House.

Comack, Elizabeth (1996) Women in Trouble, Halifax: Fernwood Publishing.

Crewe, Ben (2005) "Prisoner Society in the Era of Hard Drugs", Punishment and Society, 7(4): 457-481.

Culhane, Claire (1991). No Longer Barred From Prison: Social Injustice in Canada, Montreal: Black Rose Books.

Culhane, Claire (1985). Still Barred From Prison: Social Injustice in Canada, Montreal: Black Rose Books.

Culhane, Claire (1979) Barred From Prison: A Personal Account, Vancouver: Pulp Press.

Dana, Jacqueline and Seán McMonagle (1997) "Deconstructing "Criminalisation": The Politics of Collective Education in the H-Blocks", Journal of Prisoners on Prisons, 8(1\&2): 67-74.

Davidson, Howard and Taylor, Jon M. (2004) “Editors' Note”, Journal of Prisoners on Prisons, 13: 1-5.

Deutsch, David (2004) “The Many Faces of Prison Education”, Journal of Prisoners on Prisons, 13: 100-110.

Gaucher, Bob (ed.) (2002) Writing As Resistance: The Journal of Prisoners on Prisons Anthology (1988-2002), Toronto: Canadian Scholars Press Inc.

Gaucher, Bob (1989) "The Canadian Penal Press: A Documentation and Analysis", Journal of Prisoners on Prisons, 2(1): 3-24.

Ghunna, Michael Mac Giolla (2002[1996-1997]) "Cultural Struggle and a Drama Project", in B. Gaucher (ed.), Writing As Resistance: The Journal of Prisoners on Prisons Anthology (1988-2002), Toronto: Canadian Scholars' Press Inc., pp. 7174. Originally appeared in the Journal of Prisoners on Prisons, 7(1): 7-9.

Gilmore, Ruth W. (2007) Golden Gulag: Prisons, Surplus, Crisis, and Opposition in Globalizing California, Berkeley: University of California Press. 
Goffman, Erving (1961) Asylums: Essays on the Social Situation of Mental Patients and Other Inmates, New York: Anchor Books.

Graves, Daniel (2004) "Freedom Fighter for Literacy", Journal of Prisoners on Prisons, 13: 92-95.

Harris, Daniel H. (2004) “Educational Needs of Texas Prisoners”, Journal of Prisoners on Prisons, 13: 57-59.

Hassine, Victor (2002[1999]) "Letter to Joanna", in B. Gaucher (ed.), Writing As Resistance: The Journal of Prisoners on Prisons Anthology (1988-2002), Toronto: Canadian Scholars' Press, pp. 58-63. Originally appeared in the Journal of Prisoners on Prisons, 10(1\&2): 40-45.

Hassine, Victor (1998) "When Victims Knead Victims", Journal of Prisoners on Prisons, 9(2): 39-42.

Hassine, Victor (1997) "School Daze”, Journal of Prisoners on Prisons, 8(1\&2): 3746.

Horii, Gayle K. (1988-1989) "Inner Limits", Journal of Prisoners on Prisons, 1(2): 5-7.

Huckelbury, Jr., Charles. (2004) “The Mushroom Farm”, Journal of Prisoners on Prisons, 13: 31-45.

Huckelbury, Jr., Charles (2002[1999]) "Writing on the Walls: It Isn't Just Graffiti”, in B. Gaucher (ed.), Writing As Resistance: The Journal of Prisoners on Prisons Anthology (1988-2002), Toronto: Canadian Scholars' Press Inc., pp. 50-57. Originally appeared in the Journal of Prisoners on Prisons, 10(1\&2): 32-39.

Inderbitzin, Michelle (2007) "Inside a Maximum-Security Juvenile Training School: Institutional Attempts to Redefine the American Dream and 'Normalize' Incarcerated Youth", Punishment and Society, 9(3): 235-251.

Jones, Ray (1992) "A Coincidence of Interests: Prison Higher Education in Massachusetts", Journal of Prisoners on Prisons, 4(1): 3-20.

Liebling, A., Price, D. and Elliott, C. (1999) “Appreciative Inquiry and Relationships in Prison", Punishment and Society, 1(1): 71-98.

Lynes, Dennis (1992) “On Prison Hope and Education”, Journal of Prisoners on Prisons, 4(1): 53-55.

MacLean, Brian D. (1992) "Post-Secondary Education in the Prison: Cognitive and Moral Development or Social Control?", Journal of Prisoners on Prisons, 4(1): 21-28.

Martel, Joane (2001) "Telling the Story: A Study in the Segregation of Women Prisoners", Social Justice, 28(1): 196-215.

Mayhew, Jo-Ann (1988) “Corrections Is A Male Enterprise”, Journal of Prisoners on Prisons, 1(1): 11-21.

McMaster, Gregory J. (2002[1999]). "Maximum Ink", in B. Gaucher (ed.), Writing As Resistance: The Journal of Prisoners on Prisons Anthology (1988-2002), Toronto: Canadian Scholars' Press Inc., pp. 64-70. Originally appeared in the Journal of Prisoners on Prisons, 10(1\&2): 46-52.

McKeown, Laurence. (2001) Out of Time: Irish Republican Prisoners Long Kesh 1972-2000, Belfast: Beyond the Pale. 
Murphy, P.J. (1998) "Some Post-Mortem Reflections on the Cancellation of University Programs in Canada's Prisons", Journal of Prisoners on Prisons, 9(1): 37-54.

Nagelsen, Susan (2004) "What Have We Got to Lose?", Journal of Prisoners on Prisons, 13: 133-139.

Piché, Justin (2006) Restorative Prisons?, Unpublished Master's Thesis, Ottawa: Department of Criminology, University of Ottawa.

Rafferty, Patrick (2004) "Out of Bounds: The Message Is the Medium", Journal of Prisoners on Prisons, 13: 46-56.

Richards, Stephen C. (2004) "Penitentiary Dreams: Books Will Take You Anywhere You Want to Go", Journal of Prisoners on Prisons, 13: 60-73.

Richards, Stephen C. and Jeffrey I. Ross (2004) "Introducing the New School of Convict Criminology", Journal of Prisoners on Prisons, 13: 60-73.

Rivera, Juan (1992) "A Non-Traditional Approach to a Curriculum for Prisoners In New York State", Journal of Prisoners on Prisons, 4(1): 29-34.

Rucier, Rob (2004) "Prisoners Educating Prisoners", Journal of Prisoners on Prisons, 13: 96-99.

Salah-El, Tiyo Attallah (1992) "Attaining Education in Prison Equals Prisoner Power", Journal of Prisoners on Prisons, 4(1): 45-52.

Simon, Jonathan (2000) "The 'Society of Captives' in the Era of Hyper-Incarceration", Theoretical Criminology, 4(3): 285-308.

Sykes, Gresham (1958) The Society of Captives: A Study of a Maximum Security Prison, Princeton: Princeton University Press.

Taylor, Jon M. (2004a) "Piecing together a College Education behind Bars", Journal of Prisoners on Prisons, 13: 74-91.

Taylor, Jon M. (2004b) "What Have We Learned? Hopefully to Fight the Good Fight", Journal of Prisoners on Prisons, 13: 127-132.

Taylor, Jon M. (1997) "Pell Grants for Prisoners Part Deux: It's Déjà Vu All Over Again", Journal of Prisoners on Prisons, 8(1\&2): 47-66.

Taylor, Jon M. (1989) “The Economics of Educational Rehabilitation", Journal of Prisoners on Prisons, 2(1): 57-64.

Taylor, Laurie and Stanley Cohen (1972) Psychological Survival: The Experience of Long-Term Imprisonment, New York: Penguin Books.

Terry, Charles M. (2004) "Expanding Horizons through Education: Excerpts from the Life of a Convict Criminologist", Journal of Prisoners on Prisons, 13: 16-30.

Wacquant, Loïc (2002) "The Curious Eclipse of Prison Ethnography in the Age of Mass Incarceration", Ethnography, 3(4): 371-397.

Wright, Paul (2002[1999]) "The History of Prison Legal News: The Samizdat of the American Gulag", in B. Gaucher (ed.), Writing As Resistance: The Journal of Prisoners on Prisons Anthology (1988-2002), Toronto: Canadian Scholars' Press Inc., pp. 80-89. Originally appeared in the Journal of Prisoners on Prisons, 10(1\&2): 53-62. 